\title{
Magnetic resonance imaging of an equine ependymoma
}

\author{
Stephan Leser ${ }^{7}$, Katharina Flatz ${ }^{3}$, Andreas Brühschwein ${ }^{3}$, Anna May ${ }^{1}$, Dirk Janik², Kaspar Matiasek ${ }^{2}$ und Hartmut Gerhards ${ }^{7}$
}

Equine Clinic ${ }^{1}$, Department of Veterinary Pathology, Section of Clinical and Comparative Neuropathology ${ }^{2}$ and Clinic of Small Animal Surgery and Reproduction, Centre of Clinical Veterinary Medicine ${ }^{3}$, Ludwig Maximilians University Munich

\begin{abstract}
Summary
A 16-year-old Warmblood gelding was presented with head tilt and a history of increasing numbers of seizures with alterations in consciousness. After each seizure the horse was depressed and quiet whereas before the episodes the gelding was restless, distracted and showed signs of discomfort (chewing, rolling its eyes). In the interictal period the horse was normal. Magnetic resonance imaging revealed a third ventricle mass and ventriculomegaly of the third and lateral ventricles. Histology of the mass was consistent with a well differentiated ependymoma.
\end{abstract}

Keywords: Magnetic Resonance Imaging / brain / seizures / ependymoma / cholesteatoma

\begin{abstract}
Kernspintomographie eines Ependymoms beim Pferd
Ein 16-jähriger Warmblutwallach wurde mit Kopfschiefhaltung nach links in der Klinik für Pferde vorgestellt. Vorberichtlich waren seit vier Wochen vermehrt Krampfanfälle mit Bewußtseinsveränderungen aufgefallen. Der Wallach zeigte geringgradige propriozeptive Defizite. Die Kopfschiefhaltung war geringgradig ausgeprägt und es war kein pathologischer Nystagmus sichtbar. Bei der Untersuchung der Kopfnerven wurden mittelweite Pupillen festgestellt, die nicht auf Licht reagierten. Die Sehfähigkeit war beidseits nicht eingeschränkt. Aufgrund der Befunde der neurologischen Untersuchung wurde ein intrakranieller Prozess mit Beteiligung des Mittelhirns sowie des retikulären Aktivierungssystems vermutet. Es wurde ein Therapieversuch mit systemischen Antibiotika, Kortikosteroiden und nicht-steroidalen Antiphlogistika gestartet. Da sich die Befunde des Wallachs nicht besserten, entschloss sich der Besitzer zur Euthanasie. Post mortem wurden eine Kernspintomographie, sowie eine pathohistologische Untersuchung durchgeführt. Es zeigte sich eine nicht invasiv wachsende raumfordernde Masse im dritten Ventrikel mit einem Stauungs-Hydrocephalus, sowie einer geringgradigen transtentorialen Herniation. Aufgrund der periventrikulären Hyperintensitäten (T2W und FLAIR), die auf ein vasogenes Ödem hindeuteten, wurde ein erhöhter intrakranieller Druck vermutet. Auf der Basis der Kernspintomographie-Ergebnisse wurden ein ventrikuläres Cholesteatom, ein Ependymom oder ein Tumor des Plexus choroideus als Haupt-Differentialdiagnosen in Erwägung gezogen. Die Histopathologie der Umfangsvermehrung zeigte, dass es sich dabei um ein gut differenziertes papilläres Ependymom handelte.
\end{abstract}

Schlüsselwörter: Magnetresonanztomographie / Gehirn / Krampfanfall / Ependymom / Plexuscholesteatom

\section{Signalment, History, Clinical findings}

A 16-year-old warmblood gelding was presented with a 1-year history of progressive changes in mentation and recurrent paroxysmal collapse since 4 weeks. On clinical examination vital parameters were within physiological range (heart rate $40 / \mathrm{min}$, respiratory rate $16 / \mathrm{min})$. Superficial abrasions were evident on the horses' hind limbs. On neurological examination, the gelding was depressed. The horse showed a normal gait while it revealed slight proprioceptive deficits and delayed limb placement correction. Cutaneus trunci reflex and slap test were normal. The horse displayed a mild head tilt to the left with absence of pathological nystagmus. Evaluation of the cranial nerves bilaterally revealed mid-sized nonresponsive pupils. Hence, pupillary light reflex could not be elicited while vision was not impaired. Tongue tone and cervical reflexes were physiological. Examination of tail carriage, anal tone and anal reflex revealed no abnormalities. An intracranial disease was suspected with involvement of the midbrain and reticular activating system.

Laboratory examination of blood revealed no abnormal findings. As the owner wanted the diagnostics and treatment to be cost restrictive an attempt was made to rule out infectious or inflammatory conditions by administering drugs. The horse showed no improvement upon treatment with systemic antibiotics, steroids and non-steroidal antiinflammatory drugs. The owner finally elected euthanasia and consented to extended postmortem examinations.

\section{Imaging}

A post-mortem Magnetic Resonance Imaging (MRI) of the neurocranium was performed immediately after euthanasia and cervical transection. All scans were performed with a 1.5 Tesla magnet (Magnetom Symphony, Siemens Medizintechnik, Erlangen, Germany) equipped with a spine coil and CP body array flex coil. The head and cervical spine were placed in left lateral recumbency. Images of the head and brain were acquired with T2-weighted turbo spin-echo (T2W) sequences in sagittal, dorsal and transverse planes (TR 8810 msec; TE 105). A T1-weighted 3D gradient-echo (TIW) sequence with multiplanar reconstruction images in sagittal orientation was acquired (TR 350; TE 17). Scans were accomplished by additional Fluid Attenuated Inversion Recovery (FLAIR; TR 9130; TE 127; TI 2500) and a T2*-weighted gradient echo sequence (T2*W; TR 1000; TE 28) in transverse plane. Dorsal, transverse and sagittal images of the cranial cervical spine (C1-C4) were acquired with a T2weighted turbo spin-echo sequence.

In the third ventricle, a $3.3 \mathrm{~cm}$ in length, $2.4 \mathrm{~cm}$ in width and $2.7 \mathrm{~cm}$ in height space-occupying lesion was identified. The 
mass occupied the entire 3rd ventricle and obliterated the mesencephalic duct and the interventricular foramen. The ovoid mass appeared mildly lobulated with indistinct margins. No invasion of the neuroparenchyma was seen. The lesion was surrounded by cerebrospinal fluid, especially in the rostral part. Contact to the ventricular wall was visible in several areas, mostly at the ventral surface. It had a heterogenous appearance, with mixed signal intensities in all sequences. Some areas are hypointense in T2W, FLAIR and T2*W and iso- to hyperintense in T1W. The space-occupying lesion was surrounded in T2W, FLAIR, T2*W hyperintense and T1W by hypointense areas compared to grey matter, isointense to cerebrospinal fluid (CSF). Both lateral ventricles and the third ventricle were moderately enlarged. In T2W, FLAIR and T2*W sequences a hyperintensity around the caudal part of both lateral and third ventricles was visible. A mild transtentorial herniation of the occipital lobes was seen in sagittal T2W. In all sequences multiple focal hypointensities in the cisterna magna and within the subarachnoid space of the brain caudal aspects and the cervical spine were present. This finding was accentuated in T2*W, according to susceptibility artifact consistent with gas aspiration (vacuum effect) after dissection.

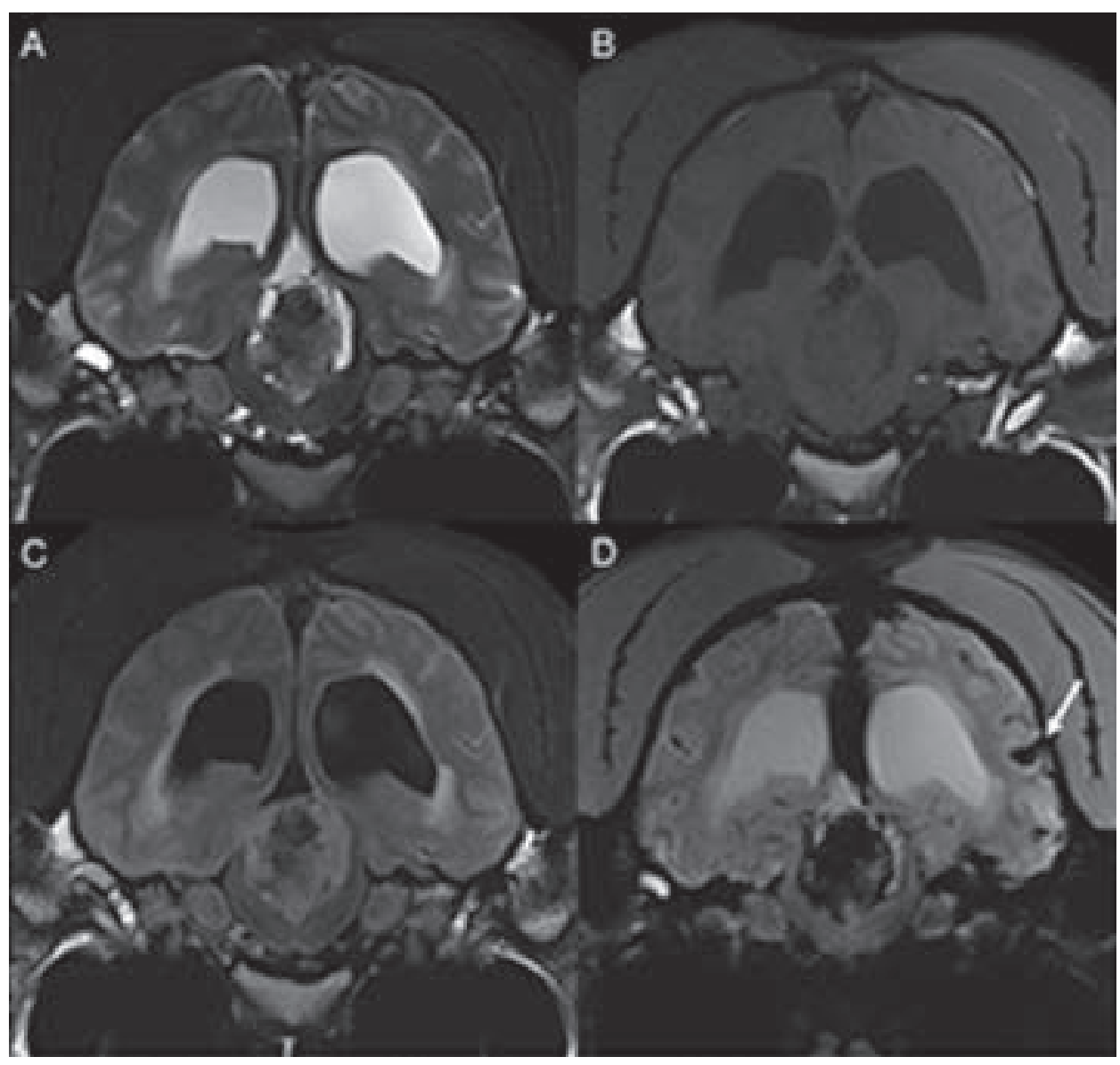

Fig. 1 In transverse images the intraventricular, lobulated mass appeared iso- to hypointense in T2W (A), T1W (B), centrally hypointense and hyperintense in the periphery, with a periventricular edema in FLAIR images (C) and markedly hypointense in $\mathrm{T}^{*}$ with gas visible within the subarachnoid space (arrow) (D)

In Transversalschnitten stellte sich die intraventrikuläre, gelappte Umfangsvermehrung in T2W (A) und T7W (B) iso- bis hypointens dar. In der FLAIR-Wichtung (C) erschien das Zentrum der Masse hypointens und die Peripherie hyperintens mit einem periventrikulären Ödem, während sie sich in der T2* gewichteten Aufnahme stark hypointens mit Gaseinschlüssen im subarachnoidalen Raum (Pfeil) darstellte (D).

Table 1 MRI findings in brain tumors which were included as differential diagnoses. Legend: isointense, $\uparrow$ hyperintense, $\downarrow$ hypointense, + signal void (+) signal void when haemorrhage present

MRT Befunde von Gehirntumoren, die als Differentialdiagnosen in Betracht gezogen wurden. Legende: $\rightarrow$ isointens, $\boldsymbol{\uparrow}$ hyperintens, $\boldsymbol{\downarrow}$ hypointens, + Signalauslöschung (+) Signalauslöschung bei Blutung

\begin{tabular}{|c|c|c|c|c|c|}
\hline Differential diagnosis & TIW & $\mathrm{T} 2 \mathrm{~W}$ & FLAIR & GRE & References \\
\hline Plexus cholesteatoma & $\begin{array}{l}\rightarrow \text { to slightly } \boldsymbol{\Downarrow} \text { to white } \\
\text { matter }(1)\end{array}$ & Low signal & $\begin{array}{l}\rightarrow \text { to } \boldsymbol{\downarrow} \text { to white matter } \\
\text { (1) }\end{array}$ & $+(1)$ & \multirow{6}{*}{$\begin{array}{l}\text { Maulet et al. } 2008 \\
\text { Wisner et al. } 2011 \\
\text { Kraft et al. } 1997 \\
\text { Vural et al. } 2006 \\
\text { Yuh et al. } 2009 \\
\text { Young et al. } 2011 \\
\text { Snyder et al. } 2006 \\
\text { Kraft et al. } 1997 \\
\text { Kraft et Gavin } 1999 \\
\text { Rodenas et al. } 2009 \\
\text { Kraft et al. } 1990\end{array}$} \\
\hline Ependymoma & $\begin{array}{l}\text { slightly } \boldsymbol{\Downarrow} \text { to slightly } \boldsymbol{\uparrow} \text {; } \\
\text { heterogeneity may be more } \\
\text { pronounced when cysts or } \\
\text { haemorrhage are present }(2-5)\end{array}$ & $\begin{array}{l}\text { moderately to markedly } \\
\uparrow(2-5)\end{array}$ & edema minimal (2-5) & & \\
\hline Plexus papilloma & $\downarrow \rightarrow \uparrow$ & $\uparrow$ & mild/moderate edema (2) & $(+)$ & \\
\hline Hemangiosarcoma & mixed signal intensity & mixed signal intensity & edema may be marked (2) & + & \\
\hline $\begin{array}{l}\text { Intraventricular } \\
\text { meningioma }\end{array}$ & $\begin{array}{l}\text { Uniformly } \rightarrow \text {, occasionally } \downarrow \\
\text { or } \uparrow\end{array}$ & $\begin{array}{l}70 \% \uparrow \text { remainder } \\
\text { being } \rightarrow\end{array}$ & edema in most cases & $(+)$ & \\
\hline $\begin{array}{l}\text { Intraventricular } \\
\text { oligodendroglioma/ } \\
\text { astrocytoma }\end{array}$ & moderately $\downarrow$ (1) & $\begin{array}{l}\uparrow \text { (typically central } \\
\text { mucinous contents) } \\
(6,7-11)\end{array}$ & $\begin{array}{l}\text { Peritumoral edema } \\
\text { minimal/moderate } \\
(6,7-11)\end{array}$ & $\begin{array}{c}(+) \\
(7-11)\end{array}$ & \\
\hline
\end{tabular}


Predominantly gas was visible around the cerebellum and a smaller amount was seen on top of multiple gyri. Apart from the latter, the cervical spine showed no abnormalities.

In summary, imaging diagnosis was a non-invasive intraventricular space-occupying lesion of the third ventricle with occlusive hydrocephalus and a mild transtentorial herniation. Increased intracranial pressure was assumed according to periventricular hyperintensities seen on T2W and FLAIR images consistent with vasogenic edema. Based on MRI results, a ventricular cholesteatoma, ependymoma and choroid plexus tumor were considered as main differentials.

\section{Diagnosis/Outcome}

On necropsy, the brain showed a mild bilateral transtentorial herniation of the occipital lobes with flattening of collicles and rostral cerebellar surface and mild caudoventral cerebellar displacement. On trimming, the brain revealed a nicely circumscribed, exophytic, $5 \times 2.5 \times 2 \mathrm{~cm}$, lobulated, intraventricular mass with pale-red, mottled, soft cut surface. With no grossly visible adhesion, it extended from the most rostral aspects of the third ventricle towards the caudal aperture of the mesencephalic aqueduct. Indentation and compression of the adjacent brain tissue was seen and the fornical plate was lifted. There was no patency of both interventricular foramens and the aqueduct. Both lateral ventricles were markedly dilated and the septum pellucidum was atrophied.

Histopathology of the lesion was consistent with a well differentiated papillary ependymoma (Huxtable et al. 2000, Carrigan et al. 1996, Miettinen et al. 1986) with mild regressive changes in terms of focal necroses and some chronic patchy hemorrhage. The mass was surrounded by a severe peritumoral edema. The compressed neuroparenchyma and the periventricular tissue presented with a moderate chronic atrophy and astrogliosis.

\section{Discussion}

This is the first report on the imaging characteristics of an intracranial ependymoma in an horse. Multiple papers feature intracranial ependymal tumors in dogs, cats, cattle, horses and humans, most of which are associated with the brain ventricles (Wisner et al. 2011 , McGill and Wells 1993, Vandevelde et al. 1985, Wright 1985, Fankhauser et al. 1974, Luginbuhl et al. 1968). Amongst ventricular masses of the equine forebrain, plexus cholesteatomas are overrepresented with an occurrence of approximately $15 \%$ to $20 \%$ of older horses (Vink-Noteboom et al. 1998, Jubb et al. 1993). They rarely manifest clinically, though. Cholesteatomas are seen arising from the plexus stroma of the third, fourth or lateral ventricles (Wisner et al. 2011 , Maulet et al. 2008, Rooney 1979). Hence, there are no differences regarding the topography if compared to other ventricular tumours, such as plexus papilloma or ependymoma. In nearly all animal species, ependymomas most often are located in the third ventricle. As in the present case, they may occlude the cerebrospinal fluid (CSF) flow at or just caudomedial to the interventricular foramen in the prethalamic aspects of the ventricle or at the rostral aperture of the mesencephalic aqueduct (Carrigan et al. 1996). The evoked hydrocephalus can cause diffuse forebrain signs that add to the sequelae of direct compression on sensitive peritumoral brain tissue (Jubb et al. 1993). In the present case, hypertensive hydrocephalus was suspected due to indicative periventricular white matter lesions. Hydrocephalus and local compression of the forebrain by the tumor both could explain decreased alertness and mental changes (Vink-Noteboom et al. 1998). Third ventricle tumors in humans rarely have been associated with cataplexia-like paroxysmal events as seen here, suggesting an impact of the pressure on the hypothalamus and arousal and sleep centres of the ascending reticular activating system (Legkonogov 1971). In contrast to previous reports on intracranial ependymoma (Carrigan et al. 1996, Heath et al. 1995, Szazados 1973), the horse also exhibited brain stem dysfunction. Bilateral internal ophthalmoplegia is attributable to the extension of the tumor into the aqueduct, interfering with the pretectal pathways and parasympathetic oculomotor nerve function. Less clear remains the unilateral head tilt since the vestibular nuclei were MRI-wise inconspicuous and there was no other unilateral lesion detected. Lateralised brain stem signs, on the other hand, together with seizures also have been described with cholesteatoma of the third ventricle in horses (Vink-Noteboom et al. 1998).

Whether the intermittent course of the clinical signs was due to remittent-relapsing hydrocephalus and edema formation of the cerebral parenchyma remains speculative (Maulet et al. 2008, Vink-Noteboom et al. 1998).

Since the clinical picture is unspecific for the type of lesion, the MRI features may provide a better insight. MRI already has been proven successful in diagnosing brain masses in horses (Audigie et al. 2004, Spoormakers et al. 2003, Arencibia et al. 2001, Westbrook and Kaut 1998) but there are no references to ependymomas in this species. Instead, Maulet et al. (2008) described the MR appearance of cholesteatoma in the lateral ventricles of a horse. Enlarged lateral ventricles with periventricular edema, caused by disturbance of the CSF flow due to the large mass, were visible. As in cholesteatoma the mass was surrounded by CSF in all three planes, confirming the non-invasive character of the mass. The intraventricular mass had a predominant hypointense signal on gradient echo images and low signal on T2W images due to hemosiderin within the mass. It was isointense to hypointense on TIW and FLAIR images. Additionally, a T2 hyperintensity was seen, consistent with central fluid pockets. Due to the similar MR signal pattern and the high incidence in older horses intraventricular cholesteatoma was our main differential diagnosis. T1W iso- to hyperintense and T2W hypointense signal, which is accentuated to signal voids in $\mathrm{T} 2 * \mathrm{~W}$ are consistent with early subacute hemorrhage (Thomas et al. 1997). This is an unspecific finding and was described with metastatic hemangiosarcoma (Dennler et al. 2007), hemangioma (Eichelberger et al. 2011) and intratumoral hemorrhage in choroid plexus tumors in dogs (Wisner et al. 2011). With a mixed signal intensity in T1W and T2W and a signal void (T2*) hemangiosarcomas appear in dogs. As metastases they may present as multiple mass lesions or a solitary mass. According to the signal intensities a metastatic hemangiosarcoma was possible and a common neoplasia in equine, but this has not been described as an intraventricular mass yet and normally distribute to the grey-white matter interface (Wisner et al. 2011). 
Choroid plexus papillomas were described as hypointense on T1W images and hyperintense on PDW and T2W images in dogs and were therefore be considered improbable (Thomas et al. 1996). As well, ependymomas appear slightly hypointense to hyperintense in TIW and moderately to markedly hyperintense in T2W in other species (McGill and Wells 1993, Vandevelde et al. 1985, Fankhauser et al. 1974, Luginbuhl et al. 1968) this differential diagnosis seemed to be unlikely.

Intravenous contrast medium application would have provided further information for the characterization of the neoplasia, but was not possible in our post-mortem study. Marked and heterogeneous contrast enhancement has been described in dogs for ependymomas, marked and homogenous enhancement for choroid plexus papillomas (Wisner et al. 2011 ) and rim enhancement for cholesterol granulomas (Lovett et al. 2012).

In this case, the MR signal of the mass was similar to that described for cholesteatoma or a metastatic hemangiosarcoma. Considering the location of the neoplasia cholesteatoma remained the main differential diagnosis.

To our knowledge this is the first description of the MRI appearance of an equine ependymoma. Compared to the similar appearance of cholesteatoma in MRI, ependymoma should be considered as a differential, if a space-occupying lesion is present within the third ventricle.

\section{References}

Arencibia A., Vazquez J. M., Ramirez J. A., Ramirez G., Vilar J. M., Rivero M. A., Alayon S. and Gil F. (2001) Magnetic resonance imaging of the normal equine brain. Vet. Radiol. Ultrasound 42, 405-408

Audigie F., Tapprest J., George C., Didierlaurent D., Foucher N., Faurie F., Houssin M. and Denoix J. M. (2004) Magnetic resonance imaging of a brain abscess in a 10-month-old filly. Vet. Radiol. Ultrasound 45, 210-215

Carrigan M. J., Higgins R. J., Carlson G. P. and Naydan D. K. (1996) Equine papillary ependymoma. Vet. Pathol. 33, 77-80

Dennler M., Lange E.-M., Schmied O. and Kaser-Hotz B. (2007) Imaging diagnosis - Metastatic hemangiosarcoma causing cerebral haemorrhage in a dog. Vet. Radiol. Ultrasound 48, 138-140

Eichelberger B. M., Kraft S. L., Halsey C. H. C., Park R. D., Miller M. $D$. and Klopp L. (2011) Imaging diagnosis - Magnetic Resonance Imaging findings of primary cerebral hemangioma. Vet. Radiol. Ultrasound 52, 188-191

Fankhauser R., Luginbuhl H. and McGrath J. T. (1974) Tumours of the nervous system. Bull. WHO 50, 55-57

Heath S. E., Peter A. T., Janovitz E. B., Selvakumar R. and Sandusky G. E. (1995) Ependymoma of the neurohypophysis and hypernatremia in a horse. J. Am. Vet. Med. Assoc. 207, 738-741

Huxtable C. R., de Lahunta A., Summers B. A. and Divers T. (2000) Marginal Siderosis and degenerative myelopathy: a manifestation of chronic subarachnoid hemorrhage in a horse with a myxopapillary ependymoma. Vet. Pathol. 37, 483-485

Jubb K. V. F., Kennedy D. C. and Palmer N. (1993) Pathology of domestic animals, 4th edition San Diego; Academic Press Inc., 334

Kraft S. L., Gavin P. R., Leathers C. W., Wendling L. R., Frenier S. and Dorn R. V. (1990) Diffuse cerebral and leptomeningeal astrocytoma in dogs: MR features. J. Comput. Assist. Tomogr. 14, 555-560

Kraft S. L., Gavin P. R., DeHaan C., Moore M., Wendling L. R. and Leathers C. W. (1997) Retrospective review of 50 canine intracranial tumors evaluated by magnetic resonance imaging. J. Vet. Intern. Med. 11, 218-225
Kraft S. L. and Gavin P. R. (1999) Intracranial neoplasia. Clin. Tech. Small Anim. Pract. 14, 112-123

Legkonogov V. A. (1971) Cataplectoid and narcoleptic seizures in primary tumors of the 3rd brain ventricle. Zh. Nevropatol. Psikhiatr. Im. S. S. Korsakova 71, 1299-304 [Article in Russian]

Lovett M. C., Fenner W. R., Watson A. T. and Hostutler R. A. (2012) Imaging diagnosis - MRI characteristics of a fourth ventricular cholesterol granuloma in a dog. Vet. Radiol. Ultrasound 53, 650-654

Luginbuhl H., Fankhauser R. and McGrath J.T. (1968) Spontaneous neoplasms of the nervous system in animals. Progr. Neurol. Surg. 2, 105-107

Maulet B. E. B., Bestbier M., Jose-Cunilleras E., Scrine J. A. and Murray $R$. (2008) Magnetic resonance imaging of a cholesterol granuloma and hydrocephalus in a horse. Equine Vet. Educ. 20, 74-79

McGill I. S. and Wells G. A. (1993) Neuropathological findings in cattle with clinically suspect but histologically unconfirmed bovine spongiform encephalopathy (BSE). J. Comp. Pathol. 108, 241-260

Miettinen M., Clark R. and Virtanen I. (1986) Intermediate filament proteins in choroid plexus and ependyma and their tumours. Am. J. Pathol. 123, 231-240

Rodenas S., Pumarola M., Gaitero L., Zamora A. and Anor S. (2009) Magnetic resonance imaging findings in 40 dogs with histologically confirmed intracranial tumours. Vet. J. doi:10.1016/ i.tvil.2009.10.011

Rooney J. R. (2006) Cerebral cholesteatoma (in a mare). Modern Vet. Pract. 60, 726

Snyder J. M., Shofer F. S., Van Winkle T. J. and Massicotte C. (2006) Canine intracranial primary neoplasia: 173 cases (1986-2003). J. Vet. Intern. Med. 20, 669-675

Spoormakers T. J. P., Ensink J. M., Goehring L. S., Koeman J. P., Braake F. T., van der Vlugt-Meijer R. H. and van den Belt A. J. M. (2003) Brain abscess as a metastatic manifestation of strangles: symptomatology and the use of magnetic resonance imaging as a diagnostic aid. Equine Vet J 35, 146-151

Szazados I. (1973) Ependymoma as the cause of severe brain symptoms in a horse. Dtsch Tieraerztl Wochenschr 80, 57. German

Thomas W. B., Wheeler S. J., Kramer R. and Kornegay J. N. (1996) Magnetic resonance imaging features of primary brain tumors in dogs. Vet. Radiol. Ultrasound 37, 20-27

Thomas W. B., Adams W. H., McGavin M. D. and Gompf R. E. (1997) Magnetic Resonance Imaging appearance of intracranial haemorrhage secondary to cerebral vascular malformation in a dog. Vet. Radiol. Ultrasound 38, 371-375

Vandevelde M., Fankhauser R. and Luginbuhl H. (1985) Immunocytochemical studies in canine neuroectodermal brain tumors. Acta Neuropathol. 66, 111-116

Vink-Noteboom M., Junker K., van den Ingh T. S. G. A. M. and Dik K. J. (1998) Computed tomography of cholesterinic granulomas in the choroid plexus of horses. Vet. Radiol. Ultrasound 39, 512-516

Vural S. A., Besalti O., Ilhan F., Ozak A. and Hallgur M. (2006) Ventricular ependymoma in a German Shepherd dog. Vet. J. 172, 185-187

Westbrook C. and Kaut C. (1998) Image weighting and contrast. In: MRI in Practice, 2nd edition, Blackwell Publishng, Oxford, 17-46

Wisner E. R., Dickinson P. J. and Higgins R. J. (2011) Magnetic resonance imaging features of canine intracranial neoplasia. Vet. Radiol. Ultrasound 52; Suppl. 1, S52-S61

Wright J. A. (1985) The pathological features associated with spinal tumors in 29 dogs. J. Comp. Pathol. 95, 549-557

Young B. D., Levine J. M., Porter B. F., Chen-Allen A. V., Rossmeis/ J. H., Platt S. R., Kent M., Fosgate G. T. and Schatzberg S. J. (2010) Magnetic resonance imaging features of intracranial astrocytomas and oligodendrogliomas in dogs. Vet. Rad. Ultrasound 52, 132-141

Yuh E. L., Barkovich A. J. and Gupta N. (2009) Imaging of ependymomas: MRI and CT. Childs Nerv. Syst. 25, 1203-1213

Dr. Anna May

Georgenstraße 39

80799 München

annamay@gmx.de 